\title{
Detection and Identification of Bacillus anthracis: From Conventional to Molecular Microbiology Methods
}

\begin{abstract}
Aleksandra A. Zasada
Department of Sera and Vaccines Evaluation, National Institute of Public Health—National Institute of Hygiene, Chocimska 24, 00-791 Warsaw, Poland; azasada@pzh.gov.pl

Received: 31 December 2019; Accepted: 15 January 2020; Published: 16 January 2020

Abstract: Rapid and reliable identification of Bacillus anthracis is of great importance, especially in the event of suspected deliberate release of anthrax spores. However, the identification of B. anthracis is challenging due to its high similarity to closely related species. Since Amerithrax in 2001, a lot of effort has been made to develop rapid methods for detection and identification of this microorganism with special focus on easy-to-perform rapid tests for first-line responders. This article presents an overview of the evolution of B. anthracis identification methods from the time of the first description of the microorganism until the present day.
\end{abstract}

Keywords: Bacillus anthracis; detection; identification; rapid tests; microbiological methods; molecular microbiology methods; biosensors; molecular markers

\section{Introduction}

Bacillus anthracis is an etiological agent of anthrax - a serious infectious disease in animals and humans with a very long history. It is believed that the first record of anthrax is in the Bible in Exodus, chapters 7-9. The disease was well known by the Greeks and Romans as its typical symptoms were described in the writings of Homer (ca. 1000 B.C.), Hippocrates (ca. 400 B.C.), Virgil (70-19 B.C.), and Galen (ca. 200 A.D.). Anthrax was a major worldwide cause of death for animals until the end of the 19 th century [1,2]. Also, human cases occurred frequently in persons that had come into contact with sick and dead animals and with animal-derived products contaminated with B. anthracis spores. For example, in the 17th century, a widespread anthrax epidemic in Europe, called "black bane", was related to a large number of deaths among animals and humans. It was estimated that 60,000 people died due to the B. anthracis infection in 1613 alone [1,3].

Due to the high economic impact of anthrax epidemics in livestock as well as the seriousness of human infections, the disease attracted the attention of microbiologists. Also, it is probably for these reasons that $B$. anthracis became the basis for the development of bacteriology and microbiological diagnostics. The 19th century was especially fruitful in terms of the study of anthrax. In 1823 Barthelemy demonstrated the infectiousness of the disease; in 1838 Delafond observed the bacilli bacteria for the first time; in 1863-1864 Davaine demonstrated the transmissibility of anthrax; and in 1864 Tiegel and Klebs demonstrated that the infectivity of infectious material was lost on filtration through cay filters. Robert Koch also studied anthrax bacilli and formulated his famous Postulates in 1877 proving that B. anthracis was the cause of anthrax [2]. Moreover, Robert Koch's observation that B. anthracis produced spores under starvation conditions together with the observation that the spores were extremely resistant to a variety of physical and chemical treatments helped in the understanding of the epidemiology of the disease and the formulation of efficient rules for the prevention of dissemination 
of the disease. It also highlighted the possibility that B. anthracis could become a biological weapon in the following decades [1].

The infective form of B. anthracis is spores. The spores germinate in a host organism (human or animal) to produce the vegetative forms which rapidly multiply and express the anthrax toxins and the poly-D-glutamic acid capsule - the major pathogenicity factors coded by genes located on the virulence plasmids pXO1 and pXO2, respectively. The anthrax toxins consist of three synergistically acting proteins: protective antigen (PA), edema factor (EF), and lethal factor (LF). PA in combination with EF forms the edema toxin and PA in combination with LF forms the lethal toxin. The toxins are responsible for the characteristic signs and clinical symptoms of the disease whereas the poly-D-glutamic acid capsule protects the bacterium from phagocytosis [4].

In the 20th century anthrax was still one of the most significant diseases globally and the annual incidence of human cases of anthrax worldwide, estimated by the World Health Organization (WHO) in 1958, was 20,000-100,000 [1]. However, due to the development of an anthrax vaccine for animals and improvement of hygienic conditions for farmers and workers using animal-derivates, anthrax became sporadic in developed countries in the second half of the 20th century. Interest in anthrax, with special focus on detection and identification of B. anthracis in environmental and clinical samples, increased again in 2001 after the bioterrorist attacks in the USA called Amerithrax [5]. It was also at this time that rapid and easy-to-perform tests for use by first-line responders (e.g., firefighters, soldiers, police officers, and emergency medical personnel), were most needed. Together with the development of sophisticated microbiological and molecular biology methods, this situation resulted in a rapid increase in scientific publications concerning new methods for B. anthracis detection and identification; however, many were verified as being related to unspecific reactions.

\section{Challenges for B. anthracis Identification}

The difficulties in identification of $B$. anthracis are related to the high phenotypic and genetic similarity of this species to Bacillus cereus and other closely related species. The similarity is so high that some researchers have considered B. anthracis to be a pathogenic variant of B. cereus. This thesis was probably presented for the first time by Smith and co-workers in 1946 [6] and the scientific discussion on this subject has been ongoing for several decades. Other genetically, closely related species of Bacillus genus that are widely distributed in the environment include Bacillus thuringiensis, Bacillus mycoides, Bacillus pseudomycoides, and Bacillus weihenstephanensis. The genome similarity between $B$. anthracis and B. cereus, B. thuringiensis, B. mycoides, B. pseudomycoides, and B. weihenstephanensis is so significant that all these species have been included in one bacterial group called B. cereus Group sensu lato [7-9]. Even B. anthracis virulence plasmids or their parts may be transferred to closely related species [10-13].

Challenging are also differences between clinical and environmental samples containing $B$. anthracis and the approach taken should depend on the type of samples being examined. Whereas vegetative cells are expected in fresh clinical samples, in environmental samples spores are expected, which are the infective form of the bacteria. On the one hand antigen content of vegetative cells and spores differs, which must be considered when antigen-based approaches are used [14]. On the other hand, spores are highly resistant to adverse environmental conditions including temperature, radiation, common disinfectants, and many other chemicals and viable spores might still be present in extracted DNA samples causing the risk of laboratory-acquired infection [15]. Even the filtration of DNA samples might not provide 100\% removal of viable spores from the samples [16].

Moreover, environmental samples may contain various microorganisms and their spores, as well as various unidentified substances that can interfere with components of a test causing the reduction of the sensitivity and even inhibition of the reaction or false-positive results due to cross-reactivity.

\section{Conventional Microbiological Methods}

Application of conventional microbiological methods for bacterial identification is always related to the necessity of culture of the microorganisms. Conventional methods of B. anthracis identification 
include growth on selective media, lack of hemolysis, lack of motility, capsule staining, gamma phage lysis, 'String-of-pearls' reaction, and susceptibility to penicillin.

Conventional microbiological methods are the gold standard for identification of bacteria but might be misleading in the case of B. anthracis. This is because many B. anthracis phenotypic features, such as lack of motility, lack of hemolysis, gamma phage lysis, and susceptibility to penicillin, can be exhibited by B. cereus isolates [17-21]. On the other hand, hemolytic $B$. anthracis strains, as well as ones resistant to penicillin and gamma phage, have also been isolated [17,18,22-24]. Moreover, application of conventional microbiological methods requires culture and handling of living microorganisms, which is always related to the risk of laboratory-acquired infections.

\subsection{Selective Media}

Polymyxin-Lysozyme-EDTA-Thallous acetate (PLET) agar is the most common selective medium for B. anthracis. It is heart infusion agar supplemented with polymyxin B, lysozyme, ethylene diamine tetra acetic acid (EDTA), and thallous acetate. PLET agar seems to be the most effective medium for isolation of $B$. anthracis from mixtures containing other spore-forming bacilli. Colonies of $B$. anthracis on PLET agar appear small, white, domed, and circular [25]. However, thallous acetate is highly toxic and therefore the use of PLET medium is excluded in some countries due to work and safety regulations [26].

Also, semi-selective media are available. R \& F Anthrax Chromogenic Agar (ChrA) is a semiselective medium which contains cycloheximide, polymyxin $\mathrm{B}$, and X-Indoxyl-choline phosphate (X-CP). X-CP detects the enzyme phosphatidylcholine phospholipase $\mathrm{C}$ (PCPLC) which is produced by $B$. anthracis but also B. cereus and B. thuringiensis. B. anthracis colonies on ChrA appear rough, with a ground-glass texture, and are cream to pale teal-blue after $24 \mathrm{~h}$ of incubation while turning teal-blue with a large white rim after $48 \mathrm{~h}$. B. cereus and B. thuringiensis colonies are dark teal-blue within $24 \mathrm{~h}$. This is because of differences between these Bacillus species in the rate of PCPLC production. The rate of production of this enzyme is about 10 times lower for $B$. anthracis than for $B$. cereus and B. thuringiensis $[20,27]$. Anthrax Blood Agar (ABA) contains cycloheximide, polymyxin B, trimethoprim, and sulfamethoxazole as a selective supplement. B. anthracis colonies on ABA are non-hemolytic, white, creamy or gray-colored. Cereus Ident Agar and Chromogenic Bacillus Cereus Agar contain polymyxin $\mathrm{B}$, trimethoprim, and the chromogenic substrate 5-bromo-4-chloro-3-indolyl-ß-glucopyranoside. The chromogenic substrate is cleaved by the enzyme B-glucosidase produced by the majority of Bacillus spp. and results in the formation of blue/green colonies. However, $B$. anthracis colonies on these media are white to creamy [26].

\subsection{Capsule Staining}

The presence of capsulated cells of B. anthracis might be confirmed by M'Fadyean staining with polychrome methylene blue or India ink staining. Polychrome methylene blue is a mixture of methylene blue and other homologs, such as azure A and azure B, which are produced during methylene blue storage by its oxidation. After staining, the B. anthracis cells are visible under a microscope as blue-black, square-ended bacilli surrounded by pink capsules. However, the $B$. anthracis capsule loses its affinity for methylene blue during putrefaction and therefore the capsule might not be visible in $\mathrm{M}^{\prime}$ Fadyean staining when samples from partially decomposed carcasses are investigated [4].

The capsule can also be exposed using India ink. The capsule is visible as a transparent halo around the bacterial cells. However, the method seems to be less sensitive than M'Fadyean staining [4].

\subsection{The Phage Lysis Test}

In 1931 Cowles described a bacteriophage which was active on B. anthracis but not specific for that species [28]. Twenty years later, McCloy isolated a bacteriophage which was active for 171 B. anthracis strains and 2 of 54 B. cereus strains tested. However, the phage failed to produce lysis of smooth variants of B. anthracis [29]. Finally, Brown and Cherry isolated gamma $(\gamma)$ phage which had the ability to lyse 
B. anthracis (including smooth forms) but not B. cereus [30]. The $\gamma$ phage is still used for B. anthracis identification $[4,31]$. The specificity of this test is estimated at $96 \%$, as a small number of other Bacillus spp. and non-Bacillus spp. environmental strains revealed to be susceptible to $\gamma$ phage [32].

\section{4. 'String-of-Pearls' Reaction}

The 'string-of-pearls' reaction was described by Jensen and Kleemeyer in 1953 [33]. It is based on the phenomenon that B. anthracis growing on a solid medium, such as Tryptose Agar, containing $0.05-0.5$ units of penicillin per $\mathrm{ml}$ at $37^{\circ} \mathrm{C}$ for $3-6 \mathrm{~h}$, forms large, spherical cells occurring in chains which resemble a string of pearls. The test was used historically and currently is not recommended.

\section{DNA Amplification-Based Methods}

The invention of the DNA amplification method using the polymerase chain reaction (PCR) by Kary B. Mullis in 1983 provided new possibilities for the identification of microorganisms. This was also reflected in the identification of $B$. anthracis.

DNA amplification-based methods have some advantages, such as a lack of the necessity to culture the microorganisms and the possibility to test inactivated samples, which make these methods safer than conventional methods.

\subsection{PCR and Real-Time PCR}

The principle for DNA amplification-based identification of microorganisms is the selection of appropriate genetic markers. The most widely used genetic markers for $B$. anthracis identification are located on anthrax virulence plasmids pXO1 and pXO2. There are usually genes coding components of anthrax toxin (protective antigen, edema factor, lethal factor) located on pXO1 and genes coding the capsule located on pXO2 (e.g., [4,34,35]).

The anthrax toxin and the capsule are virulence factors and their detection also provides information about the pathogenic properties of the strain. In general, the lack of any of the virulence plasmids decreases the pathogenic properties of the $B$. anthracis strain $[2,36,37]$. However, because the plasmids can be lost by $B$. anthracis as well as transferred to other bacilli from the B. cereus Group sensu lato, researchers have tried to identify chromosomal markers restricted to B. anthracis $[10,19,36,38,39]$. Selection of a chromosomal marker appropriate for $B$. anthracis identification has proved to be challenging. A lot of proposed markers have transpired to be unspecific. As an example, the following chromosomal markers can be mentioned: Ba813 [40,41], BA-5449 [42,43], ORF vrrA [44,45], and rpoB [46, 47]. Application of DNA sequencing enables detection-specific single nucleotide polymorphisms (SNPs) specific for B. anthracis in selected chromosomal markers. However, the use of DNA sequencing is complicated in the field. Therefore, the use of various molecular probes, HRM as well as PCR-RFLP, for detection of specific point mutations has been proposed; for example, PCR-RFLP of SG-850 marker (also called SG-749 due to its amplicon size in B. anthracis) [48] and RSI-PCR of plcR marker [49]. According to current data, both methods are considered to be specific, but require time-consuming post-PCR manipulations. Easterday et al. [50] proposed the application of minor groove binding (MGB) probes specific for the point mutation in the plcR gene of B. anthracis and real-time PCR. However, a delayed positive signal can be obtained for some B. cereus strains, which limits the usefulness of the assay.

Nevertheless, the detection of SNPs in the field by first-line responders in cases of suspected anthrax release is challenging. Currently, only two types of tests are available on the market for field application by first-line responders: rapid lateral flow assays described further in the article and PCR systems for field screening. PCR systems for field screening of $B$. anthracis include: JBAIDS (BioFire Defense Inc., Salt Lake City, UT, USA), FilmArray (BioFire, Salt Lake City, UT, USA), RAZOR EX (BioFire, Salt Lake City, UT, USA), T-COR 4 and newer version T-COR 8 (Tecracore, Rockville, MD, USA), POCKIT (GeneReach USA, Lexington, MA, USA), and Bio-Seeq PLUS (Smiths Detection, Edgewood, MD, USA). All the systems are based on real-time PCR technology and can be used with 
dedicated reagent kits. FilmArray enables investigation of one sample at a time for 27 genetic targets of 17 pathogens (BioTreat Panel), including three targets for B. anthracis: pXO1, pXO2, and chromosomal. RAZOR EX enables analysis of one sample at a time for simultaneous testing of ten pathogens (Ten Target Screen Kit), including a pXO2 assay for B. anthracis. T-COR 4 and T-COR 8 enable analysis of up to four and eight samples at a time, respectively. For B. anthracis detection, pXO1 and pXO2 assays are available (two separate kits for T-COR 4 and one combined kit for T-COR 8). Reagent kits for the systems mentioned above are available in a freeze-dried format and can be stored at room temperature. POCKIT enables analysis of up to eight samples at a time and for B. anthracis detection three assays targeting pXO1, pXO2, and chromosomal PL3 markers are available. The reagents are produced in a dry format, but recommended storage temperature is $4{ }^{\circ} \mathrm{C}$. The reaction time is about one hour for all the systems [51-54].

Real-time PCR has some advantages compared to PCR, such as the possibility of quantification of the synthesized product and the lack of post-PCR manipulations for detection of results. However, both techniques require precise temperature changes and therefore dedicated apparatuses are necessary. This disadvantage might be overcome by isothermal DNA amplification methods.

\subsection{Isothermal DNA Amplification Methods}

DNA amplification in isothermal conditions is a very promising tool and several methods have been described, such as recombinase polymerase amplification (RPA), helicase-dependent amplification (HDA), loop-mediated isothermal amplification (LAMP), rolling circle amplification (RCA), isothermal and chimeric primer-initiated amplification of nucleic acids (ICAN), strand displacement amplification (SDA), single primer isothermal amplification (SPIA), and polymerase Spiral Reaction (PSR).

Application of LAMP for B. anthracis identification was described by Qiao et al. [55] using pag (pXO1), capB (pXO2), and Ba813 (chromosomal) markers, and by Kurosaki et al. [56] using pagA (pXO1), capB (pXO2), and sap (chromosomal) markers. In the LAMP assay, a set of six primers for each marker is needed and the amplification is conducted by a strand-displacing DNA polymerase for about an hour at $60-65^{\circ} \mathrm{C}$. A result of the reaction is a mixture of various sized amplicons, visible on the agarose gel as a ladder-like pattern of bands, because the LAMP products consist of several inverted-repeat structures. The primers designed by Kurosaki et al. have subsequently been applied by other researchers who have revealed very limited specificity of the assay [57].

The RPA assay for B. anthracis detection was proposed by Euler et al. [58]. In the assay, a target sequence should be 80-400 bp in size. A pair of primers is used for the reaction and the amplification occurs thanks to the action of three proteins: a strand-displacing polymerase, a recombinase, and a single-stranded DNA binding protein. The reaction is conducted for about $30 \mathrm{~min}$ at $38{ }^{\circ} \mathrm{C}$. Euler et al. [58] designed RPA primers for $p a g A$ (pXO1) and capC (pXO2), whereas Bentahir et al. [59] designed RPA primers for BA_5345 (the chromosomal marker), lef (pXO1), and capA (pXO2). High specificity of the results was shown. On the other hand, Zasada et al. [57] (for RPA assays) applied primers for $p a g A$ and $c a p B$ commonly used in PCR and revealed high specificity for pagA markers and limited specificity for $c a p B$ markers.

In the HDA, a strand-displacing polymerase, a single-stranded DNA binding protein, a helicase, and a pair of primers are involved in the reaction, which is conducted for about $90 \mathrm{~min}$ at $65^{\circ} \mathrm{C}$. Zasada et al. [57] tried to apply the assay for B. anthracis identification based on pag $A$ and capB markers but, due to the small size of the amplification products, ranging from 80 to $120 \mathrm{bp}$, a high level of cross reactivity with other members of the $B$. cereus Group was observed.

The amplicons obtained in the above-mentioned isothermal amplification methods can be visualized by conventional agarose gel electrophoresis as well as with the use of lateral flow dipsticks [57]. Also, application of colorimetric methods for LAMP amplicon visualization was described with the use of fluorescent DNA intercalating dyes (e.g., SYBR Gold, EvaGreen, and QuantiFluor), metal ion indicators (indication of $\mathrm{Mg}^{2+}$ ), such as hydroxynaphthol blue (HNB) and calcein, and pH-sensitive 
dyes, such as neutral red and phenol red [55,60-62]. Some of these are added to the pre-reaction solution; and therefore, the reaction progress can be observed directly in real time.

\section{Antigen-Based Identification Methods}

An alternative approach for detection of $B$. anthracis is antigen detection by immunoassay. Antibodies for various antigens have been selected, such as glycoprotein $\mathrm{BclA}$, which is a major component of the exosporium of $B$. anthracis spores [63], as well as oligosaccharide epitopes of BclA [63,64], extracellular antigen 1 EA1, which is a major S-layer component of $B$. anthracis $[14,65]$, the protective antigen PA, which is a component of anthrax toxin [66] and poly-D-glutamic capsule [67]. The selection of an appropriate target antigen for the assay depends on the type of tested samples because different antigens are exposed on the surface of $B$. anthracis vegetative cells and spores. Also, cross reactivity with other members of $B$. cereus Group has been observed $[63,64,68]$.

Immunoassays applied for $B$. anthracis identification include flow cytometry assays combined with fluorescein-labeled antibodies [69] and FRET (Förster resonance energy transfer) [70,71], ELISA [63], Luminex assay [64], a magnetic particle fluorogenic immunoassay (MPFIA) [72], ABICAP immunofiltration, a lateral flow assay [65,73,74], biosensors [75], and many others.

Lateral flow assays (LFA) are the second group of tests commercially available for first-line responders. These tests are easy to perform and no equipment is required. In the assay, the capturelabeled antibody binds to its target antigen and flows along a chromatography strip by capillary force. Then, the antibody-antigen complexes and free-labeled antibodies are captured by secondary antibodies immobilized at two regions on the strip forming a test line and a control line, respectively [76]. Results of the test can be read by eye within $15 \mathrm{~min}$. Additionally, some manufacturers offer portable reading devices [77]. However, comparison of lateral flow tests reveals very low sensitivity, in practice lower than the sensitivity declared by the manufacturer, and in the case of complex samples, such as environmental and clinical samples, the lateral flow assay often suffers from interference from particle components in the tested samples [73,76].

A luminescent adenylate cyclase assay for detection of active edema factor in B. anthracis culture was developed [78]. The assay is based on the EF-dose response decrease in luminescence, which may be specifically reverted by anti-EF antibodies. The assay enables not only identification of $B$. anthracis in cultures but also gives information about expression of one of the key pathogenicity factors of these bacteria.

Immunological methods are also used for anthrax diagnostics to identify cellular immunity developed post infection. However, these methods are useful for retrospective diagnostics because several days are needed to develop specific antibodies during the infection. The most common method for detection and quantification of an antibody immune response is enzyme-linked immunosorbent assay (ELISA). The assay was developed for the detection of antibodies against various antigens, such as protective antigen [79], capsular antigen [80], and lethal factor [81]. Chitlaru et al. [82] generated a list of 84 in vivo-expressed B. anthracis immunogens that can be used in serodiagnostics and vaccine development.

Recently, Bar-Haim et al. [83] proposed a novel approach of diagnostics based on cellular reactivity of host cells with specific pathogen antigens. In this cell-based activation immunoassay the presence of interferon-gamma-producing (IFN $\gamma$-producing) activated cells might be detected in peripheral blood samples 3-5 days earlier than serum antibodies.

As an alternative to detection of specific antibodies, detection of B. anthracis biomarkers in clinical samples has been proposed [84]. The biomarkers have been identified by the proteomic assay and might be detected in serum samples at 3 to $6 \mathrm{~h}$ post-infection in an animal model. However, detection of the biomarkers could be achieved only after removal of highly abundant serum proteins by chromatography. 


\section{Biosensors}

Currently, biosensors are the most promising technology for rapid, highly sensitive and specific detection and identification of $B$. anthracis with the potential for their use as portable devices. A biosensor comprises biological recognition molecules immobilized on a signal transducer which transforms the signal into readable output. According to the signal transduction, biosensors can be classified as electrochemical (amperometric, potentiometric, and conductometric), optical, piezoelectric, and thermal sensors [85]. The majority of developed biosensors for B. anthracis identification rely on antibodies (immunosensors) or nucleic acid probes (genosensors) as the recognition molecules. The time necessary for obtaining results varies from a few minutes to a few hours.

\subsection{Nucleic Acid Probes and Genosensors}

Nucleic acid probes bind with specific DNA markers. DNA markers used for B. anthracis detection with biosensors are similar to those described above for DNA amplification-based methods.

For example, Raveendran et al. [86] developed a DNA biosensor based on the cyclic voltammetry (CV) redox peaks. In the biosensor, a self-assembled layer of tiol-linked pagA specific probe and mercaptohexanol ( $\mathrm{MCH})$ immobilized on the gold electrode. Hybridization of target DNA to the probe results in CV peak current and potential change. Ziółkowski et al. [87] also developed a voltametric biosensor but it contains a stem-loop probe linked to the gold electrode for recognition of the pag $A$ marker. The presence of the pagA marker in the sample causes opening of the loop of the probe by hybridization with the target marker and a change in registered electrochemical signal. Hao et al. [88] applied a quartz crystal microbalance (QCM) biosensor for detection of BA813 chromosomal markers and pagA markers. In this biosensor, a thiol-modified DNA probe is attached to the QCM gold surface. Hybridization of the probe with the target marker amplified in asymmetric PCR causes a mass increase and a decrease in the resonance frequency. An example of optical DNA biosensors is a biosensor based on a photonic crystal structure used in a total-internal-reflection (PC-TIR) sensor and applied for detection of lef ( $\mathrm{pXO1)}$ marker of B. anthracis. In this assay, the biotinylated probe is immobilized on the sensor via biotin-streptavidin interactions. The addition of target DNA causes hybridization with the probe and a significant increase in the resonance wavelength [89].

\subsection{Antibody Probes and Immunosensors}

Antibody probes bind with B. anthracis antigens. Antigens used for B. anthracis detection with biosensors are similar to those described above for immunoassays.

An example of this type of biosensor is a metal-enhanced electrochemical immunosensor which comprises specific antibodies self-assembled onto a gold quartz crystal electrode via cystamine bond. A solid-phase monolayer of silver underpotentially deposited onto the cystamine modified-Au-electrode surface is used as the redox probe. When the antibody-modified electrode is exposed to spores, complexes of the antigen-antibody are formed on the surface of the electrode and variation in the redox current is observed [90]. Another approach involves the use of an ultrasensitive portable capillary biosensor (UPAC). The capillary is an enclosed system that acts as the flow cell, the waveguide, and the solid support for immobilized antibody probes. An evanescent excitation generates a signal from an antigen-antibody-fluorophore complex, which propagates along the capillary and is guided to the detector [90]. McGovern et al. [91] proposed application of lead magnesium niobate-lead titanate/tin (PMN-PT/Sn) piezoelectric microcantilever sensors (PEMS) for detection of B. anthracis spores. In this approach, the specific antibodies are immobilized on the platinum electrode of the PMN-PT layer. An amperometric immunoassay for detection of B. anthracis spores was developed by Waller at al. [92]. The assay includes immunomagnetic separation to capture the spores from a sample and amperometric measurement.

A quartz crystal microbalance sensor has also been used for antigen-based detection, similar to the DNA biosensor described above. In the assay designed by Hao et al. [93], antibodies were immobilized 
onto the gold electrode with protein A on a mixed self-assembled monolayer of 11-mercaptoundecanoic acid (11-MUA) and 6-mercaptohexan-1-ol (6-MHO) as an adhesive layer.

\subsection{Aptamers and Peptide-Nucleic Acid Chimera Probes}

It is worth mentioning an additional two types of biosensors: biosensors using aptamers as probes (aptasensors) and biosensors using peptide-nucleic acid chimeras (PNAs) as probes. Aptamers are single-stranded DNA or RNA oligonucleotides which are able to bind specifically to various targets, such as toxins and microorganisms, due to their unique three-dimensional structures. PNAs are synthetic particles that can be used for detection of DNA markers [75]. However, both approaches have not been widely used for B. anthracis identification yet, and very few papers have been published on this subject. Mazzaracchio et al. [94] developed an impedimetric aptasensor for single-step detection of B. anthracis spore simulants (B. cereus spores). Bruno et al. [95] developed an aptamer-magnetic bead- electrochemiluminescence assay for B. anthracis detection. Zhang et al. [96] proposed a sandwich-hybridization DNA detection system with PNA probes for detection of pag $A$ markers.

Most of the biosensors developed and described in the scientific literature (both immunosensors and genosensors) have been tested on a very limited number of strains or even only on B. anthracis surrogates. Therefore, despite the initial high specificity of the assays, they might suffer from nonspecific reactions similar to those occurring in PCR and other antigen-based identification methods.

Table 1 presents the comparison of detection limit for selected B. anthracis detection assays.

Table 1. Comparison of detection limit for selected B. anthracis detection assays.

\begin{tabular}{|c|c|c|c|}
\hline Assay & Detected Marker & Limit of Detection & Reference \\
\hline PCR & cya & $\begin{array}{l}10^{3} \text { copies of } \\
\text { plasmid/reaction } \\
2 \times 10^{4} \text { spores/reaction }\end{array}$ & [34] \\
\hline real-time PCR (FRET) & rров & 1 pg DNA/reaction & [46] \\
\hline real-time PCR (MGB) & plcR & $100 \mathrm{fg}$ DNA/reaction & [50] \\
\hline RAZOR EX & capB & $100 \mathrm{fg}$ DNA/reaction & [51] \\
\hline RAZOR EX & $\operatorname{pag} A$ & $10 \mathrm{fg}$ DNA/reaction & [51] \\
\hline FilmArray & pOX1, pOX2 & $\begin{array}{l}200 \text { spores/reaction } \\
2000 \text { spores/mL }\end{array}$ & [52] \\
\hline T-COR 4 & pXO2 & $\begin{array}{l}200 \text { spores/reaction } \\
2000 \text { spores/mL }\end{array}$ & [52] \\
\hline POCKIT & $\mathrm{pXO} 2$ & $\begin{array}{l}200 \text { spores/reaction } \\
2000 \text { spores/mL }\end{array}$ & [52] \\
\hline LAMP & $\mathrm{Ba} 813, p a g, c a p B$ & $\begin{array}{l}10 \text { spores/reaction } \\
100 \text { spores/2 mg powder }\end{array}$ & [55] \\
\hline LAMP & pag, cap, sap & $\begin{array}{l}>10 \mathrm{fg} / \text { reaction3-6 } \\
\text { CFU/reaction }\end{array}$ & [56] \\
\hline RPA & $\operatorname{pag} A$ & $\begin{array}{l}\text { 100-1000 genome } \\
\text { copies/reaction }\end{array}$ & [57] \\
\hline LFA-Anthrax BioTreat Alert & - & $10^{7}$ spores $/ \mathrm{mL}$ & [73] \\
\hline LFA-SMART II Anthrax Spores Detection Kit & - & $10^{8}$ spores $/ \mathrm{mL}$ & {$[73]$} \\
\hline Piezoelectric biosensor & - & $10^{3} \mathrm{CFU} / \mathrm{mL}$ & [93] \\
\hline Voltametric biosensor & $\operatorname{pag} A$ & $5.7 \mathrm{nM} /$ reaction & [87] \\
\hline Impedimetric aptasensor & - & $3 \times 10^{3} \mathrm{CFU} / \mathrm{mL}$ & [94] \\
\hline
\end{tabular}

Abbreviations: PCR, polymerase chain reaction; FRET, Förster resonance energy transfer; MGB, minor groove binding; LAMP, loop-mediated isothermal amplification; RPA, recombinase polymerase amplification; LFA, lateral flow assay; $\mathrm{CFU}$, colony forming unit.

\section{MALDI-TOF MS}

Matrix-assisted laser desorption ionization time-of-flight (MALDI-TOF) mass spectrometry (MS) has been applied for identification of microorganisms and, currently, is broadly used in medical and veterinary diagnostic laboratories (e.g., MALDI-TOF mass spectrometers with a database of mass spectra for most common microorganisms are available commercially). This method was also applied 
for B. anthracis identification from pure culture as well as directly from clinical and environmental samples [97-100]. However, despite the fact that the results of identification might be obtained within several minutes, false-positive and false-negative results are an important risk. Moreover, the method can only be used in the laboratory due to the significant size of the apparatus.

\section{Conclusions}

From the time of recognition of microorganisms as causative agents of diseases in humans and animals, B. anthracis has been a pathogen of special interest. A lot of effort has been made to find reliable methods for the identification of this species. Since the advent of the threat of bioterrorism, these efforts have focused on the development of rapid, sensitive, and specific assays. In particular, portable, easy-to-use devices for first-line responders are needed. Significant progress has been made in the rapidity of tests, where results might be obtained within a few minutes. Even using conventional PCR, results can be obtained within less than an hour [101]. However, despite progress in molecular biology and the rapid development of increasingly sophisticated methods, researchers still face the same problems (i.e., the similarity of B. anthracis to closely related species which are common in the environment). For these reasons, it is recommended to confirm positive results with additional tests. Also, limitations of the applied tests must be kept in mind, especially in terms of limit detection, to avoid mistakes caused by false-negative results for which public health, economic, and social consequences might be very high. False-negative results may affect the successful treatment of affected individuals. The treatment must be implemented at the early stage of infection to prevent death, especially in case of inhalational anthrax. On the other hand, the false-positive results may cause public fear in scenarios of bio-terror and tremendous calamity-response logistic and public implications.

Funding: TheArticle Processing Charges have been covered by Fundacja "HIGIEJA", Warsaw, Poland.

Acknowledgments: The photos of colonies, Gram and M'Fadyean staining used in the graphical abstract have been obtained from Public Health Image Library CDC (https://phil.cdc.gov/).

Conflicts of Interest: The author declares no conflicts of interest.

\section{References}

1. Schwartz, M.D. Jekyll and Mr. Hyde: A short history of anthrax. Mol. Asp. Med. 2009, 30, 347-355. [CrossRef] [PubMed]

2. Turnbull, P.C.B. Introduction: Anthrax history, Disease and Ecology. In Anthrax; Koehler, T.M., Ed.; Springer: Berlin/Heidelberg, Germany, 2002; Chapter 1; p. 1.

3. Schmid, G.; Kaufmann, A. Anthrax in Europe: Its epidemiology, clinical characteristics, and role in bioterrorism. Clin. Microb. Infect. 2002, 8, 479-488. [CrossRef] [PubMed]

4. Turnbull, P.C.B. Guidelines for the Surveillance and Control of Anthrax in Human and Animals, 3rd ed.; World Health Organization: Geneva, Switzerland, 1998.

5. Burke, L.K.; Brown, C.P.; Johnson, T.M. Historical data analysis of hospital discharges related to the Amerithrax attack in Florida. Perspect. Health Inf. Manag. 2016, 13, 1.

6. Smith, N.R.; Gordon, R.E.; Clark, F.E. Aerobic Mesophilic Sporeforming Bacteria (No. 559); US Department of Agriculture, Miscellaneous Publication: Washington, DC, USA, 1946.

7. Francis, K.P.; Mayr, R.; von Stetten, F.; Stewart, G.S.; Schrer, S. Discrimination of psychrotrophic and mesophilic strains of the Bacillus cereus group by PCR targeting of major cold shock protein genes. Appl. Environ. Microbiol. 1998, 64, 3525-3529. [CrossRef]

8. Lechner, S.; Mayr, R.; Francis, K.P.; Pruss, B.M.; Kaplan, T.; Wiessner-Gunkel, E.; Stewart, G.S.; Scherer, S. Bacillus weihenstephanensis sp. nov. is a new psychrotolerant species of the Bacillus cereus group. Int. J. Syst. Bacteriol. 1998, 48, 1373-1382. [CrossRef]

9. Leonard, C.; Chen, Y.; Hahillon, J. Diversity and differential distribution of IS231, IS232 and IS240 among Bacillus cereus, Bacillus thuringiensis and Bacillus mycoides. Microbiology 1997, 143, 2537-2547. [CrossRef]

10. Battisti, L.; Green, B.D.; Thorne, C.B. Mating system for transfer of plasmids among Bacillus anthracis, Bacillus cereus and Bacillus thuringiensis. J. Bacteriol. 1985, 162, 543-550. [CrossRef] 
11. Hoffmaster, A.R.; Ravel, J.; Rasko, D.A.; Chapman, G.D.; Chute, M.D.; Marston, C.K.; De, B.K.; Sacchi, C.T.; Fitzgerald, C.; Mayer, L.W.; et al. Identification of anthrax toxin genes in a Bacillus cereus associated with an illness resembling inhalation anthrax. Proc. Natl. Acad. Sci. USA 2004, 101, 8449-8454. [CrossRef]

12. Hoffmaster, A.R.; Hill, K.K.; Gee, J.E.; Marston, C.K.; De, B.K.; Popovic, T.; Sue, D.; Wilkins, P.P.; Avashia, S.B.; Drumgoole, R.; et al. Characterization of Bacillus cereus isolates associated with fatal pneumonias: Strains are closely related to Bacillus anthracis and harbor B. anthracis virulence genes. J. Clin. Microbiol. 2006, 44, 3352-3360. [CrossRef]

13. Klee, S.R.; Brzuszkiewicz, E.B.; Nattermann, H.; Brüggemann, H.; Dupke, S.; Wollherr, A.; Franz, T.; Pauli, G.; Appel, B.; Liebl, W.; et al. The genome of a Bacillus isolate causing anthrax in chimpanzees combines chromosomal properties of B. cereus with B. anthracis virulence plasmids. PLoS ONE 2010, 5, e10986. [CrossRef]

14. Wang, D.B.; Yang, R.; Zhang, Z.P.; Bi, L.J.; You, X.Y.; Wei, H.P.; Zhou, Y.F.; Yu, Z.; Zhang, X.E. Detection of $B$. anthracis spores and vegetative cells with the same monoclonal antibodies. PLoS ONE 2009, 4, e7810. [CrossRef] [PubMed]

15. Dauphin, L.A.; Moser, B.D.; Bowen, M.D. Evaluation of five commercial nucleic acid extraction kits for their ability to inactivate Bacillus anthracis spores and comparison of DNA yields from spores and spiked environmental samples. J. Microbiol. Methods 2009, 76, 30-37. [CrossRef] [PubMed]

16. Dauphin, L.A.; Bowen, M.D. A simple method for the rapid removal of Bacillus anthracis spores from DNA preparations. J. Microbiol. Methods 2009, 76, 212-214. [CrossRef] [PubMed]

17. Abshire, T.G.; Brown, J.E.; Ezzell, J.W. Production and validation of the use of gamma phage for identification of Bacillus anthracis. J. Clin. Microbiol. 2005, 43, 4780-4788. [CrossRef]

18. Davison, S.; Couture-Tosi, E.; Candela, T.; Mock, M.; Fouet, A. Identification of the Bacillus anthracis gamma phage receptor. J. Bacteriol. 2005, 187, 6742-6749. [CrossRef]

19. Dib, E.G.; Dib, S.A.; Korkmaz, D.A.; Mobarakai, N.K.; Glaser, J.B. Nonhemolytic, nonmotile gram-positive rods indicative of Bacillus anthracis. Emerg. Infect. Dis. 2003, 9, 1013-1015. [CrossRef]

20. Luna, V.A.; Peak, K.K.; Veguilla, W.O.; Reeves, F.; Heberlein-Larson, L.; Cannons, A.C.; Amuso, P.; Cattani, J. Use of two selective media and a broth motility test can aid in identification or exclusion of Bacillus anthracis. J. Clin. Microbiol. 2005, 43, 4336-4341. [CrossRef]

21. Turnbull, P.C.B. Definitive identification of Bacillus anthracis-A review. J. Appl. Microbiol. 1999, 87, $237-240$. [CrossRef]

22. Bradaric, N.; Punda-Polic, V. Cutaneous anthrax due to penicillin-resistant Bacillus anthracis transmitted by an insect bite. Lancet 1992, 340, 306-307. [CrossRef]

23. Chen, Y.; Tenover, F.C.; Koehler, T.M. $\beta$-lactamase gene expression in a penicillin-resistant Bacillus anthracis strain. Antimicrob. Agents Chemother. 2004, 48, 4873-4877. [CrossRef]

24. Okutani, A.; Inoue, S.; Morikawa, S. Complete genome sequences of penicillin-resistant Bacillus anthracis strain PCr, isolated from bone powder. Microbiol. Resour. Announc. 2019, 8, e00670-e00719. [CrossRef] [PubMed]

25. Knisely, R.F. Selective medium for Bacillus anthracis. J. Bacteriol. 1966, 92, 784-786. [CrossRef] [PubMed]

26. Tomaso, H.; Bartling, C.; Al Dahouk, S.; Hagen, R.M.; Scholz, H.C.; Beyer, W.; Neubauer, H. Growth characteristics of Bacillus anthracis compared to other Bacillus spp. on the selective nutrient media Anthrax Blood Agar and Cereus Ident Agar. Syst. Appl. Microbiol. 2006, 29, 24-28. [CrossRef]

27. Marston, C.K.; Beesley, C.; Helsel, L.; Hoffmaster, A.R. Evaluation of two selective media for the isolation of Bacillus anthracis. Lett. Appl. Microbiol. 2008, 47, 25-30. [CrossRef] [PubMed]

28. Cowles, P.B. A bacteriophage for B. antharcis. J. Bacteriol. 1931, 21, 161-169. [CrossRef]

29. McCloy, E.W. Studies on lysogenic bacillus strain. I. A bacteriophage specific for B. anthracis. J. Hyg. 1951, 50, 114-125.

30. Brown, E.R.; Cherry, W.B. Specific identification of Bacillus anthracis by means of a variant bacteriophage. J. Infect. Dis. 1955, 96, 34-39. [CrossRef] [PubMed]

31. OIE World Organisation for Animal Health. Manual of Diagnostic Tests and Vaccines for Terrestrial Animals 2019. Chapter 3.1.1. Available online: https:/www.oie.int/en/international-standard-setting/terrestrial-manual/ access-online/ (accessed on 5 November 2019).

32. Kolton, C.B.; Podnecky, N.L.; Shadomy, S.V.; Gee, J.E.; Hoffmaster, A.R. Bacillus anthracis gamma phage lysis among soil bacteria: An update on test specificity. BMC Res. Notes 2017, 16, 598. [CrossRef] 
33. Jensen, J.; Kleemeyer, H. Die bakterielle Differentialdiagnose des Anthrax mittels eines neuen spezifischen Tests (Perl-schnurtest). Zentr. Bakteriol. Parasitenk. 1953, 159, 494-500.

34. Carl, M.; Hawkins, R.; Coulson, N.; Lowe, J.; Robertson, D.L.; Nelson, W.M.; Titball, R.W.; Woody, J.N. Detection of spores of Bacillus anthracis using the polymerase chain reaction. J. Infect. Dis. 1992, 165, 1145-1148. [CrossRef]

35. Makino, S.I.; Iinuma-Okada, Y.; Maruyama, T.; Ezaki, T.; Sasakawa, C.; Yoshikawa, M. Direct detection of Bacillus anthracis DNA in animals by polymerase chain reaction. J. Clin. Microbiol. 1993, 31, 547-551. [CrossRef] [PubMed]

36. Ivins, B.E.; Ezzell, J.W.; Jemski, J.; Hedlund, K.W.; Ristroph, J.D.; Leppla, S.H. Immunization studies with attenuated strains of Bacillus anthracis. Infect. Immun. 1986, 52, 454-458. [CrossRef] [PubMed]

37. Turnbull, P.C.B.; Hutson, R.A.; Ward, M.J.; Jones, M.N.; Quinn, C.P.; Finnie, N.J.; Duggleby, C.J.; Krammer, J.M.; Melling, J. Bacillus anthracis but not always anthrax. J. Appl. Microbiol. 1992, 72, 21-28. [CrossRef]

38. Helgason, E.; Ǩkstad, O.A.; Caugant, D.A.; Johansen, H.A.; Fouet, A.; Mock, M.; Hegna, I.; Kolstø, A.-B. Bacillus anthracis, Bacillus cereus and Bacillus thuringiensis-One species on the basic of genetic evidence. Appl. Environ. Microbiol. 2000, 66, 2627-2630. [CrossRef] [PubMed]

39. Cooper, C.; Buyuk, F.; Schelkle, B.; Saglam, A.G.; Celik, E.; Celebi, O.; Sahin, M.; Hawkyard, T.; Baillie, L. Virulence plasmid stability in environmentally occurring Bacillus anthracis from North East Turkey. Antonie Leeuwenhoek 2017, 110, 167-170. [CrossRef] [PubMed]

40. Patra, G.; Sylvestre, P.; Ramisse, V.; Therasse, J.; Guesdon, J.L. Isolation of a specific chromosomic DNA sequence of Bacillus anthracis and its possible use in diagnosis. FEMS Immunol. Med. Microbiol. 1996, 15, 221-231. [CrossRef]

41. Ramisse, V.; Patra, G.; Vaissaire, J.; Mock, M. The Ba813 chromosomal DNA sequence effectively traces the whole Bacillus anthracis community. J. Appl. Microbiol. 1999, 87, 224-228. [CrossRef]

42. Volokhov, D.; Pomerantsev, A.; Kivovich, V.; Rasooly, A.; Chizhikov, V. Identification of Bacillus anthracis by multiprobe microarray hybridization. Diagn. Microbiol. Infect. Dis. 2004, 49, 163-171. [CrossRef]

43. Irenge, L.M.; Gala, J.-L. Rapid detection methods for Bacillus anthracis in environmental samples: A review. App. Microbiol. Boitechnol. 2012, 93, 1411-1422. [CrossRef]

44. Andersen, G.L.; Simchock, J.M.; Wilson, K.H. Identification of a region of genetic variability among Bacillus anthracis strains and related species. J. Bacteriol. 1996, 178, 377-384. [CrossRef]

45. Jackson, P.J.; Walthers, E.A.; Kalif, A.S.; Richmond, K.L.; Adair, D.M.; Hill, K.K.; Kuske, C.R.; Andersen, G.L.; Wilson, K.H.; Hugh-Jones, M.; et al. Characterization of the variable-number tandem repeats in vrrA from different Bacillus anthracis isolates. Appl. Environ. Microbiol. 1997, 63, 1400-1405. [CrossRef] [PubMed]

46. Qi, Y.; Patra, G.; Liang, X.; Williams, L.E.; Rose, S.; Redkar, R.J.; DelVecchio, V.G. Utilization of the rpoB gene as a specific chromosomal marker for real-time PCR detection of Bacillus anthracis. Appl. Environ. Microbiol. 2001, 67, 3720-3727. [CrossRef] [PubMed]

47. Zasada, A.A.; Gierczyński, R.; Raddadi, N.; Daffonchio, D.J.; Jagielski, M. Some Bacillus thuringiensis strains share rpoB nucleotide polymorpsims also present in Bacillus anthracis. J. Clin. Microbiol. 2006, 44, 1606-1607. [CrossRef] [PubMed]

48. Daffonchio, D.; Borin, S.; Frova, G.; Gallo, R.; Mori, E.; Fani, R.; Sorlini, C. A randomly amplified polymorphic DNA marker specific for the Bacillus cereus group is diagnostic for Bacillus anthracis. Appl. Environ. Microbiol. 1999, 65, 1298-1303. [CrossRef]

49. Gierczyński, R.; Zasada, A.A.; Raddadi, N.; Merabishvili, M.; Daffonchio, D.; Rastawicki, W.; Jagielski, M. Specific Bacillus anthracis identification by a plcR-targeted restriction site insertion-PCR (RSI-PCR) assay. FEMS Microbiol. Lett. 2007, 272, 55-59. [CrossRef]

50. Easterday, W.R.; Van Ert, M.N.; Simonson, T.S.; Wagner, D.M.; Kenefic, L.J.; Allender, C.J.; Keim, P. Use of single nucleotide polymorphisms in the plcR gene for specific identification of Bacillus anthracis. J. Clin. Microbiol. 2005, 43, 1995-1997. [CrossRef]

51. Matero, P.; Hemmilä, H.; Tomaso, H.; Piiparinen, H.; Rantakokko-Jalava, K.; Nuotio, L.; Nikkari, S. Rapid field detection assays for Bacillus anthracis, Brucella spp., Francisella tularensis and Yersinia pestis. Clin. Microbiol. Infect. 2011, 17, 34-43. [CrossRef]

52. Ozanich, R.M.; Colburn, H.A.; Victry, K.D.; Bartholomew, R.A.; Arce, J.S.; Heredia-Langner, A.; Jarman, K.; Kreuzer, H.W.; Bruckner-Lea, C.J. Evaluation of PCR systems for field screening of Bacillus anthracis. Health Secur. 2017, 15, 70-80. [CrossRef] 
53. Seiner, D.R.; Colburn, H.A.; Baird, C.; Bartholomew, R.A.; Straub, T.; Victry, K.; Hutchison, J.R.; Valentine, N.; Bruckner-Lea, C.J. Evaluation of the FilmArray ${ }^{\circledR}$ system for detection of Bacillus anthracis, Francisella tularensis and Yersinia pestis. J. Appl. Microbiol. 2013, 114, 992-1000. [CrossRef]

54. Hadfield, T.; Ryan, V.; Spaulding, U.K.; Clemens, K.M.; Ota, I.M.; Brunelle, S.L. RAZOR EX Anthrax Air Detection System for detection of Bacillus anthracis spores from aerosol collection samples: Collaborative study. J. AOAC Int. 2013, 96, 392-398. [CrossRef]

55. Qiao, Y.M.; Guo, Y.C.; Zhang, X.E.; Zhou, Y.F.; Zhang, Z.P.; Wei, H.P.; Yang, R.F.; Wang, D.B. Loop-mediated isothermal amplification for rapid detection of Bacillus anthracis spores. Biotechnol. Lett. 2007, 29, 1939-1946. [CrossRef]

56. Kurosaki, Y.; Sakuma, T.; Fukuma, A.; Fujinami, Y.; Kawamoto, K.; Kamo, N.; Makino, S.I.; Yasuda, J. A simple and sensitive method for detection of Bacillus anthracis by loop-mediated isothermal amplification. J. Appl. Microbiol. 2009, 107, 1947-1956. [CrossRef] [PubMed]

57. Zasada, A.A.; Zacharczuk, K.; Formińska, K.; Wiatrzyk, A.; Ziółkowski, R.; Malinowska, E. Isothermal DNA amplification combined with lateral flow dipsticks for detection of biothreat agents. Anal. Biochem. 2018, 560, 60-66. [CrossRef] [PubMed]

58. Euler, M.; Wang, Y.; Heidenreich, D.; Patel, P.; Strohmeier, O.; Hakenberg, S.; Niedrig, M.; Hufert, F.T.; Weidmann, M. Development of a panel of recombinase polymerase amplification assays for detection of biothreat agents. J. Clin. Microbiol. 2013, 51, 1110-1117. [CrossRef] [PubMed]

59. Bentahir, M.; Ambroise, J.; Delcorps, C.; Pilo, P.; Gala, J.L. Sensitive and specific recombinase polymerase amplification assays for fast screening, detection, and identification of Bacillus anthracis in a field setting. Appl. Environ. Microbiol. 2018, 84, e00506-e00518. [CrossRef] [PubMed]

60. Tanner, N.A.; Zhang, Y.; Evans, T.C., Jr. Visual detection of isothermal nucleic acid amplification using pH-sensitive dyes. BioTechniques 2015, 58, 59-68. [CrossRef] [PubMed]

61. Goto, M.; Honda, E.; Ogua, A.; Nomoto, A.; Hanaki, K.-I. Colorimetric detection of loop-mediated isothermal amplification reaction by using hydroxyl naphthol blue. BioTechniques 2009, 46, 167-172. [CrossRef] [PubMed]

62. Zasada, A.A.; Wiatrzyk, A.; Czajka, U.; Brodzik, K.; Formińska, K.; Mosiej, E.; Prygiel, M.; Krysztopa-Grzybowska, K.; Wdowiak, K. Application of Loop-Mediated Isothermal Amplification combined with colorimetric and lateral flow dipstick visualization as the potential point-of-care testing for diphtheria. BMC Infect. Dis. 2020, in press.

63. Kuehn, A.; Kovác, P.; Saksena, R.; Bannert, N.; Klee, S.R.; Ranisch, H.; Grunow, R. Development of antibodies against anthrose tetrasaccharide for specific detection of Bacillus anthracis spores. Clin. Vaccine Immunol. 2009, 16, 1728-1737. [CrossRef]

64. Tamborrini, M.; Holzer, M.; Seeberger, P.H.; Schürch, N.; Pluschke, G. Anthrax spore detection by a luminex assay based on monoclonal antibodies that recognize anthrose-containing oligosaccharides. Clin. Vaccine Immunol. 2010, 17, 1446-1451. [CrossRef]

65. Pillai, S.P.; Prentice, K.W.; Ramage, J.G.; DePalma, L.; Sarwar, J.; Parameswaran, N.; Bell, M.; Plummer, A.; Santos, A.; Singh, A.; et al. Rapid presumptive identification of Bacillus anthracis isolates using the Tetracore RedLine Alert ${ }^{\mathrm{TM}}$ test. Health Secur. 2019, 17, 334-343. [CrossRef] [PubMed]

66. Sastry, K.S.; Tuteja, U.; Santhosh, P.K.; Lalitha, M.K.; Batra, H.V. Identification of Bacillus anthracis by a simple protective antigen-specific mAb dot-ELISA. J. Med. Microbiol. 2003, 52, 47-49. [CrossRef] [PubMed]

67. Mechaly, A.; Vitner, E.; Levy, H.; Weiss, S.; Bar-David, E.; Gur, D.; Koren, M.; Cohen, H.; Cohen, O.; Mamroud, E.; et al. Simultaneous immunodetection of anthrax, plague, and tularemia from blood cultures by use of multiplexed suspension arrays. J. Clin. Microbiol. 2018, 56, e01479-e01517. [CrossRef] [PubMed]

68. Turnbough, C.L. Discovery of phage display peptide ligands for species-specific detection of Bacillus spores. J. Microbiol. Methods 2003, 53, 263-271. [CrossRef]

69. Stopa, P.J. The flow cytometry of Bacillus anthracis spores revisited. Cytometry 2000, 41, 237-244. [CrossRef]

70. Zahavy, E.; Fisher, M.; Bromberg, A.; Olshevsky, U. Detection of frequency resonance energy transfer pair on double-labeled microsphere and Bacillus anthracis spores by flow cytometry. Appl. Environ. Microbiol. 2003, 69, 2330-2339. [CrossRef] [PubMed]

71. Cohen, N.; Zahavy, E.; Zichel, R.; Fisher, M. An internal standard approach for homogeneous TR-FRET immunoassays facilitates the detection of bacteria, biomarkers, and toxins in complex matrices. Anal. Bioanal. Chem. 2016, 408, 5179-5588. [CrossRef] 
72. Yu, H. Comparative studies of magnetic particle-based solid phase fluorogenic and electrochemiluminescent immunoassay. J. Immunol. Methods 1998, 218, 1-8. [CrossRef]

73. Zasada, A.A.; Formińska, K.; Zacharczuk, K.; Jacob, D.; Grunow, R. Comparison of eleven commercially available rapid tests for detection of Bacillus anthracis, Francisella tularensis and Yersinia pestis. Lett. Appl. Microbiol. 2015, 60, 409-413. [CrossRef]

74. Kolton, C.B.; Marston, C.K.; Stoddard, R.A.; Cossaboom, C.; Salzer, J.S.; Kozel, T.R.; Gates-Hollingsworth, M.A.; Cleveland, C.A.; Thompson, A.T.; Dalton, M.F.; et al. Detection of Bacillus anthracis in animal tissues using InBios active anthrax detect rapid test lateral flow immunoassay. Lett. Appl. Microbiol. 2019, 68, 480-484. [CrossRef]

75. Kim, J.; Gedi, V.; Lee, S.C.; Cho, J.H.; Moon, J.Y.; Yoon, M.Y. Advances in anthrax detection: Overview of bioprobes and biosensors. Appl. Biochem. Biotechnol. 2015, 176, 957-977. [CrossRef] [PubMed]

76. Wang, D.B.; Tian, B.; Zhang, Z.P.; Wang, X.Y.; Fleming, J.; Bi, L.J.; Yang, R.F.; Zhang, X.E. Detection of Bacillus anthracis spores by super-paramagnetic lateral-flow immunoassays based on "Road Closure". Biosens. Bioelectron. 2015, 67, 608-614. [CrossRef] [PubMed]

77. Bartholomew, R.A.; Ozanich, R.M.; Arce, J.S.; Engelmann, H.E.; Heredia-Langner, A.; Hofstad, B.A.; Hutchison, J.R.; Jarman, K.; Melville, A.M.; Victry, K.D.; et al. Evaluation of immunoassays and general biological indicator tests for field screening of Bacillus anthracis and ricin. Health Secur. 2017, 15, 81-96. [CrossRef] [PubMed]

78. Israeli, M.; Rotem, S.; Elia, U.; Bar-Haim, E.; Cohen, O.; Chitlaru, T. A simple luminescent adenylate-cyclase functional assay for evaluation of Bacillus anthracis edema factor activity. Toxins 2016, 8, 243. [CrossRef]

79. Semenova, V.A.; Steward-Clark, E.; Maniatis, P.; Epperson, M.; Sabnis, A.; Schiffer, J. Validation of high throughput screening of human sera for detection of anti-PA IgG by Enzyme-Linked Immunosorbent Assay (ELISA) as an emergency response to an anthrax incident. Biologicals 2017, 45, 61-68. [CrossRef]

80. Gates-Hollingsworth, M.A.; Perry, M.R.; Chen, H.; Needham, J.; Houghton, R.L.; Raychaudhuri, S.; Hubbard, M.A.; Kozel, T.R. Immunoassay for capsular antigen of Bacillus anthracis enables rapid diagnosis in a rabbit model of inhalational anthrax. PLOS ONE 2015, 10, e0126304. [CrossRef]

81. Ghosh, N.; Tomar, I.; Lukka, H.; Goel, A.K. Serodiagnosis of human cutaneous anthrax in India using an indirect anti-lethal factor IgG enzyme-linked immunosorbent assay. Clin. Vaccine Immunol. 2013, 20, $282-286$. [CrossRef]

82. Chitlaru, T.; Gat, O.; Grosfeld, H.; Inbar, I.; Gozlan, Y.; Shafferman, A. Identification of in vivo-expressed immunogenic proteins by serological proteome analysis of the Bacillus anthracis secretome. Infect. Immun. 2007, 75, 2841-2852. [CrossRef]

83. Bar-Haim, E.; Rotem, S.; Elia, U.; Bercovich-Kinori, A.; Israeli, M.; Cohen-Gihon, I.; Israeli, O.; Erez, N.; Achdout, H.; Zauberman, A.; et al. Early diagnosis of pathogen infection by cell-based activation immunoassay. Cells 2019, 8, 952. [CrossRef]

84. Sela-Abramovich, S.; Chitlaru, T.; Gat, O.; Grosfeld, H.; Cohen, O.; Shafferman, A. Novel and unique diagnostic biomarkers for Bacillus anthracis infection. Appl. Environ. Microbiol. 2009, 75, 6157-6167. [CrossRef]

85. Gooding, J. Biosensor technology for detecting biological warfare agents: Recent progress and future trends. Anal. Chim. Acta 2006, 559, 137-151. [CrossRef]

86. Raveendran, M.; Andrade, A.F.B.; Gonzalez-Rodriguez, J. Selective and sensitive electrochemical DNA biosensor for the detection of Bacillus anthracis. Int. J. Electrochem. Sci. 2016, 11, 763-776.

87. Ziółkowski, R.; Oszwałdowski, S.; Zacharczuk, K.; Zasada, A.A.; Malinowska, E. Electrochemical detection of Bacillus anthracis protective antigen gene using DNA biosensor based on stem-loop probe. J. Electrochem. Soc. 2018, 165, B187-B195. [CrossRef]

88. Hao, R.Z.; Song, H.B.; Zuo, G.M.; Yang, R.F.; Wei, H.P.; Wang, D.B.; Cui, Z.Q.; Zhang, Z.P.; Cheng, Z.X.; Zhang, X.E. DNA probe functionalized QCM biosensor based on gold nanoparticle amplification for Bacillus anthracis detection. Biosens. Bioelectron. 2011, 26, 3398-3404. [CrossRef]

89. Zhang, B.; Dallo, S.; Peterson, R.; Hussain, S.; Weitao, T.; Ye, J.Y. Detection of anthrax lef with DNA-based photonic crystal sensors. J. Biomed. Opt. 2011, 16, 127006. [CrossRef]

90. Mwilu, S.K.; Aluoch, A.O.; Miller, S.; Wong, P.; Sadik, O.A.; Fatah, A.A.; Arcilesi, R.D. Identification and quantitation of Bacillus globigii using metal enhanced electrochemical detection and capillary biosensor. Anal. Chem. 2009, 81, 7561-7570. [CrossRef] 
91. McGovern, J.P.; Shih, W.Y.; Shih, W.H. In situ detection of Bacillus anthracis spores using fully submersible, self-exciting, self-sensing PMN-PT/Sn piezoelectric microcantilevers. Analyst 2007, 132, 777-783. [CrossRef]

92. Waller, D.F.; Hew, B.E.; Holdaway, C.; Jen, M.; Peckham, G.D. Rapid detection of Bacillus anthracis spores using immunomagnetic separation and amperometry. Biosensors 2016, 6, 61. [CrossRef]

93. Hao, R.Z.; Wang, D.B.; Zhang, X.E.; Zuo, G.M.; Wei, H.P.; Yang, R.F.; Zhang, Z.P.; Cheng, Z.X.; Guo, Y.C.; Cui, Z.Q.; et al. Rapid detection of Bacillus anthracis using monoclonal antibody functionalized QCM sensor. Biosens. Bioelectron. 2009, 24, 1330-1335. [CrossRef]

94. Mazzaracchio, V.; Neagu, D.; Porchetta, A.; Marcoccio, E.; Pomponi, A.; Faggioni, G.; D’Amore, N.; Notargiacomo, A.; Pea, M.; Moscone, D.; et al. A label-free impedimetric aptasensor for the detection of Bacillus anthracis spore simulant. Biosens. Bioelectron. 2019, 126, 640-646. [CrossRef]

95. Bruno, J.G.; Kiel, J.L. In vitro selection of DNA aptamers to anthrax spores with electrochemiluminescence detection. Biosens. Bioelectron. 1999, 14, 457-464. [CrossRef]

96. Zhang, N.; Appella, D.H. Colorimetric detection of anthrax DNA with a peptide nucleic acid sandwich-hybridization assay. J. Am. Chem. Soc. 2007, 129, 8424. [CrossRef] [PubMed]

97. Lasch, P.; Beyer, W.; Nattermann, H.; Stämmler, M.; Siegbrecht, E.; Grunow, R.; Naumann, D. Identification of Bacillus anthracis by using matrix-assisted laser desorption ionization-time of flight mass spectrometry and artificial neural networks. Appl. Environ. Microbiol. 2009, 75, 7229-7242. [CrossRef]

98. Dybwad, M.; van der Laaken, A.L.; Blatny, J.M.; Paauw, A. Rapid identification of Bacillus anthracis spores in suspicious powder samples by using matrix-assisted laser desorption ionization-time of flight mass spectrometry (MALDI-TOF MS). Appl. Environ. Microbiol. 2013, 79, 5372-5383. [CrossRef] [PubMed]

99. Pauker, V.I.; Thoma, B.R.; Grass, G.; Bleichert, P.; Hanczaruk, M.; Zöller, L.; Zange, S. Improved discrimination of Bacillus anthracis from closely related species in the Bacillus cereus Sensu Lato group based on Matrix-Assisted Laser Desorption Ionization-Time of Flight Mass Spectrometry. J. Clin. Microbiol. 2018, 56, e01900-e01917. [CrossRef] [PubMed]

100. Elhanany, E.; Barak, R.; Fisher, M.; Kobiler, D.; Altboum, Z. Detection of specific Bacillus anthracis spore biomarkers by matrix-assisted laser desorption/ionization time-of-flight mass spectrometry. Rapid Commun. Mass Spectrom. 2001, 15, 2110-2116. [CrossRef] [PubMed]

101. Zasada, A.A.; Formińska, K.; Zacharczuk, K. Fast identification of Yersinia pestis, Bacillus anthracis and Francisella tularensis based on conventional PCR. Pol. J. Microbiol. 2013, 62, 453-455. [CrossRef] 